\title{
THE IMPACT OF CORRUPTION ON ECONOMIC GROWTH IN ETHIOPIA
}

\author{
Abdirahman Ali Ahmed \\ Department of Economics \\ Sakarya University, Sakarya, Adapazari, Turkey
}

\begin{abstract}
This study has mostly focused on the harmful effects of corruption on economic growth in Ethiopia and the extent of corruption as well as its forms that exist in the country including political corruption, Petty and bureaucratic corruption, judiciary, energy sector, police, land administration and social services like health and education. The study revealed that corruption in a great extent damaged the growth and economic performance in general both in reginal and federal level and shrinks the incentives of investments also corruption resulted low stimulus for innovation.
\end{abstract}

Keywords-Corruption, Growth, Ethiopia.

\section{INTRODUCTION}

Recently, the anti-corruption issue is one of the topmost priorities in the organized reform schema for development in countries including Ethiopia. For last periods, many researchers and scholars have paid their interests by their studies on evaluation to effects on corruption in economic growth and as generally the economic performance of the nations. However, to date, this matter is still in debates in terms of ethical and economic implications. Mauro (1995) shows the influence of corruption outcomes negatively to the investment and therefore, it causes negatively affects to the economic growth. As well as these gains full agreement of Brunetti \& Weder (1998), Mo (2001), Choe et. al (2013). Hypothetically, the studies reach no agreement about the effect of corruption on economic growth. Some scholars propose that corruption might be required (Leff, 1964; Huntington, 1968; Acemoglu and Verdier, 1998). Corruption works like piece-rate pay for administrators, which tempts a more efficient delivery of government services, and it offers a leeway for entrepreneurs to avoid wasteful regulations. Since this viewpoint, corruption acts as a grease that smooths operations and, hence, increases the productivity of an economy. On the other hand, corruption tends to hurt groundbreaking actions because visionaries need governmentsupplied goods, such as licenses and import quotas, more than established producers do. The willing to purchase for these goods is high and inelastic; hence, they become main targets of corruption. Furthermore, innovators have no established lobbies and networks so that they are subject to mostly substantial bribes and expropriations. Furthermore, unlike established producers, innovators are often credit-constrained and cannot find the cash to pay inducements (Murphy et al.,1993). This will lessen private investment and, hence, the stock of producible inputs in the long run. People's capacity and exertion will be allocated to rent-seeking actions in its place of fruitful investments, e.g., accumulating capital, knowledge, and skills. Additionally, corruption favors a particular class of people and forms disparity in opportunities. In addition to the shrinking of opportunities due to productivity retardation, inequality in opportunities, which is similar to revenue and prosperity inequality, will lead to blocking and sociopolitical uncertainty. Recent studies recommend that the standing corruption levels are negative to development, e.g., Gould and Amaro-Reyes (1983), United Nations (1990), and Mauro (1995). However, the real effect of corruption on economic growth and its transmission process can be established only empirically. Mauro (1995) involved in an empirical analysis of corruption by investigating the relationship between investment and corruption for 58 countries. His corruption variable is defined as the degree to which business dealings encompass corruption and questionable payment. The average proportion of total and private investment to GDP for the period between 1970 and 1985 is drawn from Barro (1991), while the corruption pointer is the simple average for the country in question for the period from 1980 to 1983 from Business International (1984). Mauro discoveries that corruption has a substantial negative effect on the proportion of investment to GDP. These outcomes are reliable with the understanding that corruption is harmful for economic growth.

\section{PROPOSED AlgorithM}

\section{Literature Review}

Studies on the corruption-economic growth nexus remains miscellaneous to date. This section analyses the literature on the effect of corruption on economic growth. It comprises an overview of corruption measures, as well as theories on the effect of corruption on growth, and it is followed by empirical studies based on indexes used in these specific studies. This is followed by determining the gap in this literature.

2.1 Empirical Studies on the Effects of Corruption on Economic Growth 


\section{International Journal of Engineering Applied Sciences and Technology, 2020 \\ Vol. 5, Issue 7, ISSN No. 2455-2143, Pages 35-40 \\ Published Online November 2020 in IJEAST (http://www.ijeast.com)}

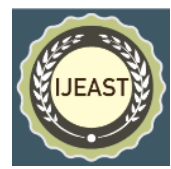

In the observed literature on economic growth, corruption is considered an significant independent variable. The common form of the equation used in the empirical studies can be specified as the following:

\section{$g t i=\beta 0 i t+\beta 1 C R i t+\beta k E k i t+u i t$}

Where $C R$ denotes to corruption, $E k$ states to the set of descriptive variables, and $u$ is the error term. The coefficient $\beta 0$ is the constant term; the coefficient $\beta 1$ is the incomplete impact of corruption on growth, and the coefficient $\beta k$ is the set of coefficients indicating the partial impact of the explanatory variables on growth.

\subsubsection{Economic Freedom Index}

There is another measure that has been used for computing corruption is the Economic Freedom Index (EFI). The EFI is a yearly index generated by the Heritage Foundation. The index measures 10 different component of economic freedom (Note 1).

According to Millor et al. (2009) The 10 Components of Economic of economic freedom offer a description of a country's economic procedures and create standards by which to measure strengths and weaknesses. The EFI shows that economic freedom is the key in producing an environment in which innovation and entrepreneurship can boom, along with fast economic growth. The scale of the index ranges from 0 to 100 . While the latter refer to most economic freedom, 0 refers no economic freedom.

Peev and Mueller (2012) studied the relationship between corruption and economic growth for 24 transition countries from 1990 to 2007. Using EFI as a proxy for corruption, they found that the more economic freedom available in a country, the higher the economic growth is experienced.

Peev and Mueller (2012) also found that high EFI in a country is an outcome of autonomous organizations. The empirical results, furthermore, show that the most important component of economic growth affecting economic growth is freedom from corruption. A rise in corruption by one unit is related with a decline in economic growth by 2.76 per cent. The interpretation of this finding is that economic freedom stimulates investment in a country, which, in turn, leads to more growth. One of the influences and impacts of corruption on economic growth is throughout foreign direct investment (FDI). This indirect effect of corruption has been highlighted by many studies in the literature.

Commonly, economists agree that the FDI inflow will lead to rise in economic growth. For example, Johnson (2006) examined 90 countries from 1980 to 2002 and recommended that foreign direct investment has a positive impact on economic growth as a result of spill-over effects of technology and physical capital inflows. He found that the inflows of foreign direct investment boost economic growth in developing countries. According to a study done by Ray (2012) on economic effects of FDI in India from 1991 to 2011, FDI has a positive impact on economic growth. He argued that this positive relationship is that FDI improves human resources and infrastructure, develops local entrepreneurship, and creates a good environment for productive investment.

Alemu (2012) experienced the association between corruption and FDI for 16 Asian economies from 1995 to 2009. Using the EFI as a measure of corruption, he initiates that corruption negatively affects economic growth. The observed results indicate that an increase in the level of corruption by 1 per cent leads to a decrease in FDI by 9.1 per cent. According to him, the negative relationship between corruption and FDI is due to the economic uncertainty that arises from corruption and, hence, affects the confidence of investors in the market, which ultimately affects economic growth.

Additional conclusion reported in this study, however, is that China and India experienced high levels of corruption and received a huge amount of FDI. He claimed that these countries can double their FDI inflows if they decrease the level of corruption. The negative relationship emphasized in this study between corruption and FDI will eventually affect the economic growth in these countries, given the important relationship between FDI and economic growth.

\section{OVER VIEW OF CORRUPTION IN ETHIOPIA}

According to The Economist in its 2017 Democracy Index, Ethiopia is an "authoritarian regime" with a score of 3.42 (out 10) and a rank of 129 out of 167 countries. The authoritarian one-party system in Ethiopia largely excludes the public from any genuine and autonomous political participation (Freedom House 2018). Ethiopia's economy has experienced strong, broad-based growth, averaging $10.3 \%$ a year from 2005/06 to $2015 / 16$, compared to a regional average of $5.4 \%$. Despite being the fastest growing economy in the region, the country is also one of the poorest. The main development challenges that Ethiopia faces is sustaining its positive economic growth and accelerating poverty reduction, which requires progress in job creation and improved governance (World Bank 2018b). Despite its astonishing and successive economic growth, Ethiopia still faces a lot of economic challenges. The main ones over the past couple of years include inflation, rising foreign exchange rate, forex shortage as foreign trade has not grown at the desired level, increasing burden of foreign debt, increasing disparity between domestic saving and investment, and corruption, among others. These have, in turn, affected the lives of the population (Hailu 2018). Early in 2018, after the unexpected resignation of Prime Minister Hailemariam Desalegn, Abiy Ahmed, Ethiopia's first leader from the Oromo ethnic group, was chosen to lead the ruling Ethiopian People's Revolutionary Democratic Front (EPRDF) coalition (BBC News 2018a; The Guardian 2018). The resignation was 


\section{International Journal of Engineering Applied Sciences and Technology, 2020 \\ Vol. 5, Issue 7, ISSN No. 2455-2143, Pages 35-40 \\ Published Online November 2020 in IJEAST (http://www.ijeast.com)}

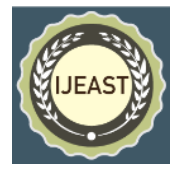

unprecedented in the east African country, and occurred amid widespread unrest that started in 2015 as demonstrations broke out against political restrictions and human rights abuses (The Guardian 2018). There was no specific trigger for these mass protests. It was more of an accumulation of years of frustration from ethnic groups who have been marginalized by the government (BBC News 2016). Nevertheless, land rights, corruption, unemployment and bad governance have come up as reasons for the widespread protests (BBC News 2017). Demonstrations by the Oromo tribe against expansion of capital city Addis Ababa into Oromo lands then flared in 2016 (Heritage Foundation 2018).

Ethiopia's government is known to "keep a tight grip on the country", and there has be no unrest on this scale in the last 25 years (BBC News 2016). By 2017, 669 people had died as a result of the anti-government protests led by activists from the Amhara and Oromia regions (BBC News 2016). The government's response was to declare a ten-month long state of emergency and to set up a human rights commission to take charge of the situation (Freedom House 2018). Accusations of security forces using live ammunition on protesters were made by the then UN High Commissioner for Human Rights. However, the Ethiopian government did not allow any international observers to investigate (BBC News 2017).

However, Abiy's efforts have been acknowledged by the international community as improving respect for human rights, reforming the business environment and making peace with Eritrea (Beech 2018).

Prime Minister Abiy Ahmed has stated that Ethiopia is facing an existential threat from the proliferation of corrupt activities, adding that "the lack of proactive media role in uncovering corrupt practices and ineffectiveness of government institutions to root out corrupt practices is endangering the country's political structure". The prime minister has also said that the fight against corruption would be his administration's top priority (Xinhua 2018). Corruption in the country ranges from petty to grand, and acts as an impediment to its development and further exacerbating poverty. Lack of accountability and transparency, low levels of democratic culture and tradition, lack of citizen participation, lack of clear regulations and authorization, low level of institutional control, absence of punishment, and centralization of authority and resources are some of the factors that contribute to corruption thriving in the country (Ayferam, Bayeh and Muchie 2015; Teshome 2016). Corruption, smuggling, tax fraud, and trafficking in narcotics, persons, arms and animal products are the key proceeds-generating crimes (US Department of State 2017b).

\section{EXTENT OF CORRUPTION}

Ethiopia ranks 107 out of 180 countries in Transparency International's 2017 Corruption Perceptions Index (CPI) (Transparency International 2018).
Worldwide Governance Indicators (WGI) by the World Bank (2018c) accord the following scores in percentile rank1 to Ethiopia:

\begin{tabular}{|l|c|c|}
\hline Indicator & $\begin{array}{l}\mathbf{2 0 1 6} \\
\text { percentile } \\
\text { rank }\end{array}$ & $\begin{array}{l}\mathbf{2 0 1 7} \\
\text { percentile } \\
\text { rank }\end{array}$ \\
\hline Control of corruption & 39.9 & 33.3 \\
\hline $\begin{array}{l}\text { Government } \\
\text { effectiveness }\end{array}$ & 28.8 & 23.6 \\
\hline $\begin{array}{l}\text { Political stability and } \\
\text { absence } \\
\text { violence/terrorism of }\end{array}$ & 7.6 & 7.6 \\
\hline Regulatory quality and & 9.4 & 9.9 \\
\hline Rule of law & 11.5 & 13.6 \\
\hline $\begin{array}{l}\text { Violence } \\
\text { accountability }\end{array}$ & & 33.7 \\
\hline
\end{tabular}

The 2017 TRACE Bribery Risk Matrix places Ethiopia in the "high" risk category, ranking it 178 out of 200 surveyed countries. Similarly, Ethiopia's Doing Business rank for 2018 is $161 / 190$ with a Distance to Frontier (DTF)2 score of 47.77 (The World Bank 2018a).

Ethiopia's economic freedom score is 52.8, making its economy the 142 out of the 170 surveyed in the 2018 Index of Economic Freedom by the Heritage Foundation. Its overall score has increased by 0.1 point, with an increase in investment freedom (which nonetheless remains poor), and improvements in judicial effectiveness and monetary freedom offsetting declines in business freedom, labor freedom and trade freedom. Ethiopia is ranked 27 of 47 countries in the sub-Saharan Africa region, and its overall score is below the regional and world averages (Heritage Foundation 2018).

Bertelsmann Stiftung's Transformation Index (BTI) 2018 ranks the country 113 out of 129 countries. It adds that corruption poses a serious and multifaceted problem to the overall wellbeing of the population and its economy. The report further states that there is a problem of capacity to control corruption at all levels, negligible political will, and diminished legal commitments to hold accountable powerful actors implicated in corruption and those who facilitated massive capital flight. According to Global Financial Intelligence, Ethiopia lost US\$26 billion to illicit financial outflows between 2004 and 2013 (Bertelsmann Stiftung 2018). Freedom House, in its 2018 Freedom in the World report, on the other hand, accords the status of "Not Free" to Ethiopia, with an aggregate score of 12/100. According to the 2018 Ibrahim Index of African Governance (IIAG), Ethiopia ranks 35 out of 54 with a score of 46.5 out of 100 in Overall Governance. 


\section{International Journal of Engineering Applied Sciences and Technology, 2020 \\ Vol. 5, Issue 7, ISSN No. 2455-2143, Pages 35-40 \\ Published Online November 2020 in IJEAST (http://www.ijeast.com)}

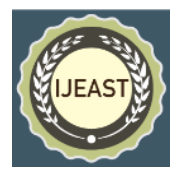

\section{FORMS OF CORRUPTION}

\subsection{Political corruption}

The widespread propagation of political corruption in Ethiopia has significantly aborted the country's democratization process, eroded the rule of law, led to the politicization of the country's civil service system, as well as the monopolization of the country's economy (Kebede 2013). Parliament and the judiciary are not independent institutions that can use their constitutional authority to hold the executive accountable. The executive uses various ways of controlling or coercing parliamentarians and the judiciary to ensure the harmonization of judicial and legislative decisions with the government's anti-democratic and repressive policies (Bertelsmann Stiftung 2018).

All of the 547 seats of the parliament are controlled by the EPRDF, that abides by unforgiving party discipline of democratic centralism (Kebede 2013; Hassan 2015; Freedom House 2018). The EPRDF "leadership discuss and decide beforehand what they want to be decided by parliament". In the current Ethiopian political culture, the party and the executives are fused, creating conditions of state capture (Kebede 2013; Hassan 2015). The regime has been accused of being kleptocratic, while reportedly being involved in no-bid contracts, embezzling from donor aid and demanding bribes (Hassan 2015). Opponents of the EPRDF find it nearly impossible to operate inside Ethiopia. Authorities frequently invoke anti-terrorism legislation against dissenters (Freedom House 2018).

In 2017, as part of an anti-graft drive (partly as a response to 2015-6 unrest), dozens of government officials, including the state minister for finance, were arrested on suspicion of corruption. Officials from the Ministry of Finance and Economic Cooperation, the capital's housing development agency, the state-run Ethiopian Sugar Corporation and the Ethiopian Roads Authority were also arrested, on charges including embezzlement and the siphoning off of billions of Birrs (Maasho 2017).

\subsection{Petty and bureaucratic corruption}

Ethiopia's bureaucracy is also considered to be complex, creating opportunities for officials and staff to attempt to circumvent rules, and therefore be more open to giving and receiving bribes to secure contracts (Wheatland 2015). The power, tax, investment and transport sectors have been identified as having the highest level of corruption, according to a study under the Federal Ethics \& Anti-Corruption Commission (FEACC) (Mulatu 2014). Petty corruption seems to exist in almost every office. Officials from the traffic police, court, customs and trade licenses office, land acquisition department, licensing, and tax collection, as well as government procurement, have faced allegations of bribery (Mulatu 2014).

\subsection{Energy sector}

Ethiopia enjoys a vast amount of renewable and nonrenewable energy resources, ranging from hydro- and solarpower to biomass and natural gas (Wheatland 2015). It is estimated that between 2005 and 2015, US\$3.4 billion was required for Ethiopia to meet its electricity development capacity. Such high levels of investment in this sector create a number of opportunities for bribery and corruption, as the huge investment sums can allow officials to skim money from budgets by overcharging for goods and services (Wheatland 2015).It has been suggested that the Ethiopian government has intentionally violated procurement and investment guidelines to maintain investment in its energy sector. For example, the government directly awarded construction contracts to the Italian company Salini without competitive bidding procedures (Wheatland 2015).

\subsection{Judiciary}

While the judiciary is formally an independent branch of the government, mechanisms that allow for checks and balances in Ethiopia are weak, courts are overburdened, and the executive branch exercises great influence over the judiciary. It is fairly common for the government to interfere in the application of the law and even in the enforcement of court orders (Martini 2015; Business Anti-Corruption Portal 2017; US Department of State 2017a; Bertelsmann Stiftung 2018). Moreover, in the name of "developmental democracy", the government has transformed its courts into another security apparatus whose job is not to question the government, but merely to rubber-stamp decisions made by the government and its security apparatus (Bertelsmann Stiftung 2018). Corruption within the judiciary at the local level is severe, but rarely reported. The judiciary fails to prevent violence in prisons. Civil rights and individual liberties are systematically violated because the judiciary and other national human rights institutions are controlled by the ruling party (Bertelsmann Stiftung 2018).

\subsection{Police}

Local police are often known to act on their own, and security forces, by and large, have impunity against their transgressions throughout the country (US Department of State 2017a). During the recent state of emergency (SOE), an executive body called the Command Post managed security policy, holding broad powers, including the ability to detain individuals, restrict speech and restrict movement. Individuals, including children, arrested by security forces during the SOE temporarily were held incommunicado. Police investigators used physical and psychological abuse to extract confessions (US Department of State 2017a). Corruption within Ethiopia's police is perceived to be rampant, and the solicitation of bribes by police officers remains a widespread problem. Companies are also known to pay the police for their security (Business Anti-Corruption Portal 2017).

\subsection{Land administration}




\section{International Journal of Engineering Applied Sciences and Technology, 2020 \\ Vol. 5, Issue 7, ISSN No. 2455-2143, Pages 35-40 \\ Published Online November 2020 in IJEAST (http://www.ijeast.com)}

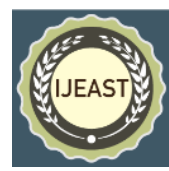

There is a high risk of corruption in Ethiopia's land administration with petty corruption, land-grabbing, corruption in the auctioning process, and state capture being common in the sector (Lindner 2014; Business AntiCorruption Portal 2017). The country's legal and institutional structure, with regard to land administration, has been criticized for being unnecessarily complicated (Lindner 2014). There are a number of elements in Ethiopia's current land administration system that can create potential entry points for corrupt activities to occur. These include: lack of clear policies, weak institutions, lack of transparency, limited public participation and capacity challenges (Lindner 2014).

\subsection{Social Services (Health and Education)}

The 2012 World Bank report on corruption in the health sector found that the sector does not suffer from pervasive corruption compared to other sectors or countries. However, the existence of corruption in the health sector cannot be denied. Corruption and fraud in the health care delivery is one of the barriers to implementing policies of health care financing (Ethiopian Public Health Institute, 2014). In the second corruption perception survey done in 2012 , household respondents were asked to assess the quality public health institutions that they had used and indicate the general trend in health services. 62\% said overall quality had improved during the previous five years, while $21 \%$ felt the quality had become worse and $17 \%$ said there had been no noticeable change. The perception report added that "the fact that almost two-fifths reported either a static situation or deterioration in the quality o services should be cause for concern to health officials' (Federal Ethics and Anti-Corruption Commission, 2012) $6.2 \%$ of the respondents answered that they had been asked to pay gratification in Woreda health offices/bureaus. $39.6 \%$ and $39.1 \%$ respondents of household and business respondents considered public health institutions as honest or very hones respectively. Another area in the health sector where risk were identified was in the referral of patients from public to private health facilities. Referral of patients from public to private health institutions is open to abuse as "medica practitioners referring patients to private clinics and hospitals with which they are associated either to generate more business for those facilities or to augment their own remuneration when they provide private treatment to those referred patients" (FEACC, 2012). Corruption in the education sector includes fraud in examinations, falsification qualification, teacher absenteeism, and favoritism towards members of the ruling party both in teacher recruitment and in student selection and assessment (FEACC, 2012). In the past years, there have been huge investments in the education sector increasing corruption risks in procurement, management and delivery of stock (building equipment, and so on) (FEACC, 2012). Nonetheless, education establishments in Ethiopia are perceived as relatively honest institutions, with $57 \%$ of the respondents in the 2012 perception survey concurring. Out of these respondents, however, only two (2) out of the 22 public institutions on the list were considered as honest by more than $50 \%$ of the respondents (FEACC, 2012). Only $2.7 \%$ of respondents said they had been asked to pay bribes in this sector. Within the business community, the public education sector is considered as honest or very honest by $46.6 \%$ of respondents (FEACC, 2012).

\section{ClasSIFICATION OF CORRUPTION RISKS AND EFFECTS}

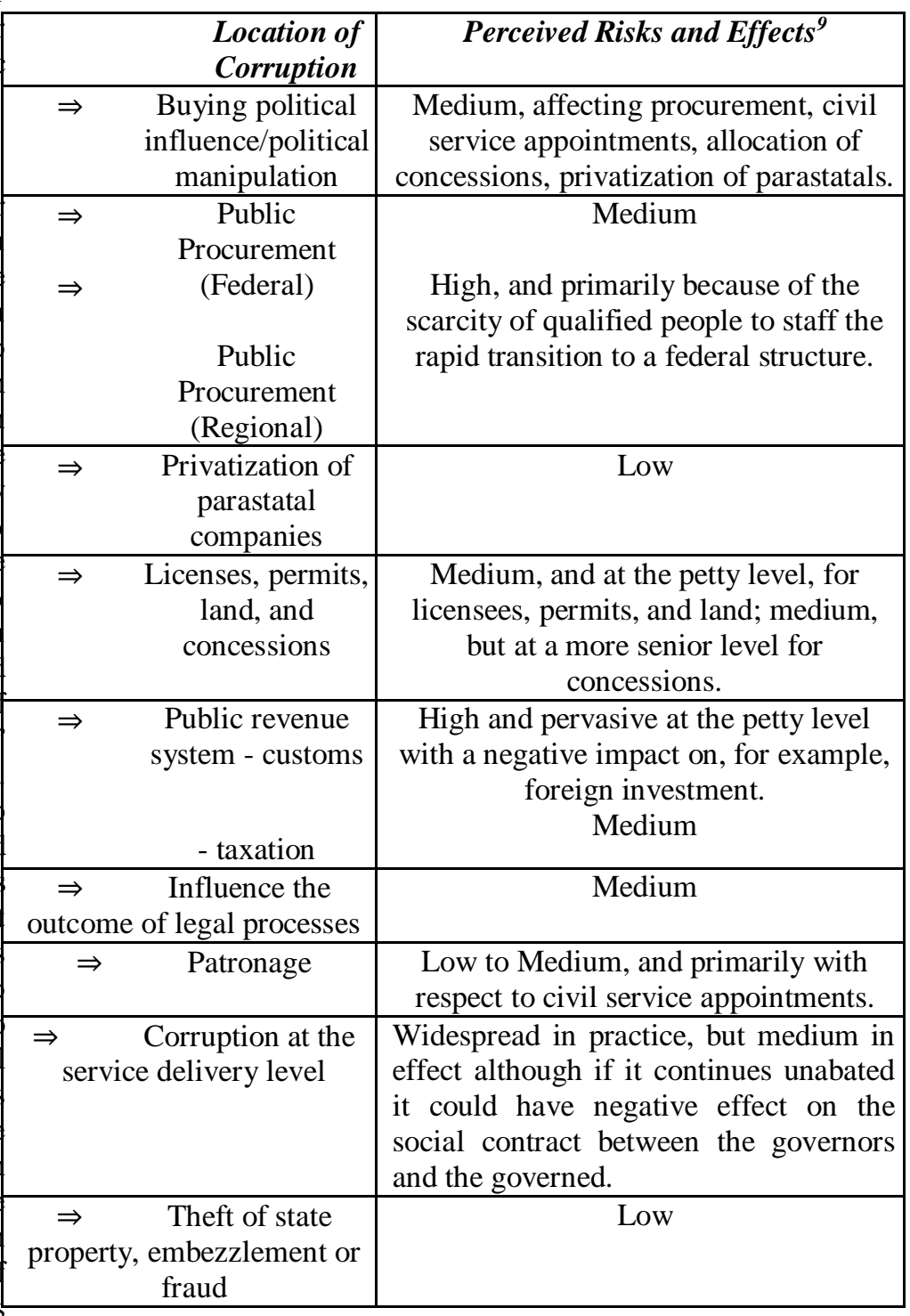

\section{CONCLUSION}

Corruption is a clear expression of political systems that are insufficient or deficient in democratic power sharing habit, checking and balancing, accountable and transparent governmental institution and procedures of the formal and ideal system of democratic governance. It is also expressed as an outcome of a self-serving political leadership and highly 


\section{International Journal of Engineering Applied Sciences and Technology, 2020 \\ Vol. 5, Issue 7, ISSN No. 2455-2143, Pages 35-40 \\ Published Online November 2020 in IJEAST (http://www.ijeast.com)}

politicized, misdirected and inefficient state framework within which individual and group private interests have priority over the collective good. In the modern Ethiopia, the political system of the country is characterized by political, social and economic state capture, absences of genuine competition among some political parties, weak and limb national governance institutions, such as the parliaments, judiciary and corruption watchdog agencies. In functional terms, what came into creation is an indulgent environment for the sudden multiplication of corruption in Ethiopia

\section{REFERENCES}

1 Alemu, A. M. (2012). Effects of Corruption on FDI Inflow in Asian Economies. Seoul Journal of Economics, 25(4),387-412.

2 Ayferam, G., Bayeh, E. and Muchie, Z. 2015. Causes and Consequences of Corruption in Ethiopia; the case of Ambo Town. Global Journal of Educational Administration and Management Vol. 2 (1), pp. 072079.

3 Ades A. and R. Di Tella (1999), "Rents, Competition, and Corruption", the American Economic Review, 89: 4, 982-993.

4 African Development Bank Group (2003), "Combating Corruption in Africa" Proceedings of the regional learning workshop, African Union conference center, Addis Ababa.

5 Africa Development Indicators (2010), "Silent and Lethal: How Quiet Corruption Undermines Africa"es Development", the World Bank.

6 Ahn, S.C., and P. Schmidt (1995), "Efficient Estimation of Models for Dynamic Panel Data", Journal of Econometrics, 68, 5-27.

7 Aidt T.S. (2003), "Economic Analysis of Corruption: A survey", The Economic Journal, 113:491, F632 F652.

8 Alonso-Borrego, C. and M. Arellano (1999): "Symmetrically normalized instrumental-variable estimation using panel data", Journal of Business and Economic Statistics, 17, 36-49.

9 Ampratwum E.F. (2008), “The Fight against Corruption and Its Implications for Development in developing and Transition Economies", Journal of Money Laundering Control11:1,76-87.

10 Anderson, T.W. and C. Hsiao (1981), "Estimation of Dynamic Models with Error Components", Journal of the American Statistical Association, 76, 598-606. Anoruo E. and H. Braha (2005), "Corruption and Economic Growth: the African Experience", Journal of Sustainable Development in Africa, Vol.7, issue 1.
11 Arellano M., and S. Bond (1991), "Tests of Specification for Panel Data: Monte Carlo Evidence and an Application to Employment Equations", Review of Economic Studies, 58, 277- 97.

12 Arellano M., and O. Bover (1995), "Another Look at the Instrumental Variable Estimation of ErrorComponents Models", Journal of Econometrics, 68, 29-51.

13 Baltagi, B. H. (2005), Econometric Analysis of Panel Data, $3^{\text {rd }}$ ed, Wiley \& Sons, New York.

14 Bardhan P. (1997), "Corruption and Development: A Review of Issues", American Economic Association, Journal of Economic Literature, 35: 3, 1320-1346.

15 Hassan, S. 2015. Aid, Predation and State Capture: The Role of Development Aid in Fuelling Corruption and Undermining Governance: The Case of Ethiopia. Research Gate.

16 Kebede, G. 2013. Political Corruption: Political and Economic State Capture in Ethiopia. European Scientific Journal Vol.9, No.35 ISSN: 1857 - 7881.

17 Leff, N. H. (1964). Economic development through bureaucratic corruption. American Behavioral Scientist, 8(3), 8-14.

18 Lindner, S. 2014. Ethiopia: Overview of Corruption in Land Administration. Transparency International.

19 Federal Ethics and Anti-Corruption Commission (FEACC). 2018. Federal Ethics and Anti-Corruption Commission - Establishment.

20 Federal Ethics and Anti-Corruption Commission (FEACC). 2012. Ethiopia Second Corruption Perception Survey, Kilimanjaro International Corporation Limited, Pp. 51-52

21 Mauro, P. (1995). Corruption and growth. The Quarterly Journal of Economics,110(3), 681712.http://dx.doi.org/10.2307/2946696

22 Mauro, P. (1997). The effects of corruption on growth, investment and government expenditure: Across-country analysis. In K. A. Elliott (Ed.), Corruption and the global economy (pp. 83-107). Washington, DC: Institute for International Economics.

23 Maasho, A. 2017. Ethiopia Arrests State Minister for Finance on Suspicion of Corruption. Thomson Reuters.

24 Transparency Ethiopia (TE). 2018. About Us.

25 Transparency International. 2018. Corruption Perceptions Index 2017. 